UDC 378.147:355.23

DOI: $10.31470 / 2415-3729-2018-8-109-122$

\title{
Motivativational Readiness of Future Officers of Missiles and Artillery Armament as a Factor of Their Professional Development
}

\section{Oleh Maslii}

Doctor of Philosophy in Pedagogy (Phd), Senior Research Assistant, Deputy Director of the Academy for Scientific Work Military Academy $\triangle 10$, Fontanska doroha Str., Odessa, Ukraine, 65000

E-mail: mon2369@ukr.net

ORCID: 0000-0003-2809-2763

Date of receipt of the article: August 02, 2018 Article accepted for publication: November 25, 2018

\section{Мотиваційна готовність майбутніх офіцерів ракетно- артилерійського озбросння як чинник їх професійного становлення}

\section{Олег Миколайович Маслій}

кандидат педагогічних наук, старший науковий співробітник, заступник начальника академії з навчальної роботи

Військова академія,

вул. Фонтанська дорога, 10 м. Одеса, Україна, 65000

Дата надходження статті: 01 серпня 2018 р. Стаття прийнята до друку: 25 листопада 2018 р.

\section{Abstract}

The article is devoted to the motivational readiness of future officers of missiles and artillery armament as a factor of their professional development. The author noted that the motives occupy an increasingly prominent place in the structure of future missile and artillery armament officers' professional training for a future 
military service. These motives are determined in the article as a person's inner encouragement to activity, connected with meeting certain needs. The benefit of this study is that a group of motives that determine the professional activity of military specialists has been identified. Moreover, the analysis of the motivational sphere gave grounds to identify the needs of the cadets: an attractiveness of the specialty, a physical training, a military honor and dignity, relations with colleagues, obtaining a civilian specialty for budgetary funds, a social status, and an extension of family traditions of military service. The motivational readiness of cadets is characterized by the appropriate orientation and the presence of the content of activities, the professional attitudes of an individual. As a result, the cadets' motivational readiness is defined as a stable system of the person's psychological formations that create appropriate states of mind and encourage military experts to work. The author has made a conclusion in the article that the professional training of a future officer of missile and artillery armament should result in the following: the qualitative performance of operational duties; the ability to make interpersonal relations with a personnel; the ability to see the point in a military service, to set goals, and to exert an insistence in reaching them, to rationally share the duties among the military servicemen, to get a job done; the ability to adapt for a change in social environment through general and military education; a desire for continuous selfdevelopment; a confidence in personal skills and correctness of the path pursued. The following three levels of motivational readiness of future officers are revealed by the author of the article: high level (characterized by a pronounced need in military professional selfdevelopment), average level (distinguished by the motivational and value structure), low level (characterized by a poor value orientation and military service guidance).

Key words: motivational readiness, needs, motives, professional guidance, cadets, military service.

\section{References}

1. Boiko, O. V. (2004). Tekhnolohiia formuvannia psykholohichnoi hotovnosti maibutnikh mahistriv viiskovo-sotsialnoho upravlinnia do vykonannia funktsii kerivnykiv-lideriv. [The technology 
of forming the psychological readiness of future masters of military and social management to perform functions of manager-leaders]. Viiskova osvita - Military education. Kyiv : Nauk.-metod. tsentr viiskovoi osvity MON Ukrainy, 14, 126-135 [in Ukrainian].

2. Hrebeniuk, H. S. (1997). Motyvatsiina hotovnist kursantiv i slukhachiv vyshchoho viiskovoho uchbovoho zakladu do profesiinoi diialnosti (na prykladi spetsialistiv pozhezhnoi bezpeky MVS Ukrainy) [Motivational readiness of cadets and students of a higher military educational institution for a professional activity (on the example of fire safety specialists of the Ministry of Internal Affairs of Ukraine)]. Extended abstract of candidate's thesis. Kyiv : Kyivskyi hum. in-t. [in Ukrainian].

3. Dmyterko-Karabyn, Kh. M. (2004). Motyvatsiina hotovnist do profesiinoi diialnosti yak psykholohichna problema. [Motivational readiness for a professional activity as a psychological problem]. Zbirnyk naukovykh prats: filosofiia, sotsiolohiia, psykholohiia Collection of scientific works: philosophy, sociology, psychology. Ivano-Frankivsk : Vyd-vo «Plai» Prykarpatskoho universytetu, 9(2), 23-32 [in Ukrainian].

4. Maksymenko, S. D., Melnyk, P. V. \& Oleksiienko, B. M. (2002). Osnovy viiskovoi psykholohii [Fundamentals of Military Psychology:]. Khmelnytskyi : Vydavnytstvo Natsionalnoi akademii PVU [in Ukrainian].

5. Potapchuk, Ye. M. (2001). Psykholohichna robota u Prykordonnykh viiskakh Ukrainy. Moralno-psykholohichne zabezpechennia sluzhbovoi diialnosti Prykordonnykh viisk Ukrainy [Psychological work in the Border Guards of Ukraine. The moralpsychological support of the activity of the Border Guard Troops of Ukraine]. Khmelnytskyi : NAPVU [in Ukrainian].

6. Yahupov, V. V. (2004). Viiskova psykholohiia [Military Psychology]. Kyiv : Tandem [in Ukrainian].

\section{Ветуп}

Зміни, що відбуваються в Збройних Силах України 3 особливою гостротою актуалізують питання підготовки військових фахівців, зокрема офіцерів ракетно-артилерійського озброєння. 
Дедалі очевиднішою є необхідність обгрунтування мотивації та мотиваційної готовності військовослужбовців до професійної діяльності з урахуванням досвіду антитерористичної операції у східних регіонах держави, стандартів підготовки НАТО, умов стану особливого періоду або мирного часу, і більш повного їх врахування під час підготовки курсантів в освітньому середовищі військових закладів вищої освіти (В3ВО).

Основною проблемою військової професійної освіти $\epsilon$ трансформація навчальної діяльності курсантів, яку вони здійснюють в освітньому середовищі ВЗВО, до виконання визначених завдань в особливий та мирний час. 3 позиції загальної теорії діяльності такий перехід відбувається по лінії трансформації мотивів, оскільки саме мотив є генеруючою ознакою діяльності. Таким чином, у військовій професійній освіті розвиток пізнавальних i професійних мотивів $\epsilon$ центральною ланкою розвитку майбутніх офіцерів ракетноартилерійського озброєння.

Аналіз наукових доробків учених дає підстави стверджувати, що в психолого-педагогічній літературі приділяється значна увага проблемам розвитку професійної мотивації військових фахівців (В. Бачевський, І. Біжан, С. Будник, П. Дзюба, Н. Генералова, А. Комишан, Я. Корнійчук, Г. Марченко та ін.). Теоретичні питання професійної підготовки майбутніх офіцерів 3 позиції формування системи військової освіти в Україні розглядалися у роботах М. Варія, О. Свсюкова, М. Коваля, М. Нещадима, В. Ягупова.

Актуальність дослідження визначається тим, що осмисленню мотиваційного чинника в професійній діяльності майбутніх офіцерів ракетно-артилерійського озброєння на даному етапі не приділяється належної уваги.

Метою статті $€$ обгрунтування сутності мотиваційної готовності майбутніх офіцерів ракетно-артилерійського озброєння до професійної діяльності та шляхів іiї формування.

\section{Матеріал і методи дослідження}

Для досягнення поставленої мети було використано теоретичні (аналіз наукової літератури 3 досліджуваної проблематики, синтез, порівняння, оцінка й узагальнення зібраних 
фактів) та емпіричні (спостереження, опитування, тестування, анкетування) методи дослідження.

\section{Результати та їх обговорення}

Готовність майбутніх офіцерів ракетно-артилерійського озброєння до професійної діяльності - складне структурносистемне утворення, яке охоплює різні сторони психіки військових фахівців і включає особистісно-мотиваційну та вольову сфери, узагальнені знання й уявлення, їх професійні навички і здібності. У формуванні готовності курсантів до професійної діяльності особливе значення має мотиваційний компонент, який є базовим у підготовці військових фахівців, оскільки поза мотивом неможлива жодна діяльність. Тому у структурі професійної готовності майбутніх офіцерів ракетно-артилерійського озброєння до професійної діяльності важливе місце займають мотиви як внутрішнє спонукання особистості до активності, пов'язане із задоволенням певних потреб (Бойко, 2004).

Мотиви формують мотиваційно-ціннісну структуру професійної діяльності військовослужбовців, що представляє взаємопов'язану сукупність їх потреб, інтересів, ціннісних орієнтацій, які забезпечують спрямованість мотивів і діяльності особистості. Зважаючи на зазначене, мотиваційну готовність майбутніх офіцерів ракетно-артилерійського озброєння до професійної діяльності розуміємо як стійку систему психологічних утворень особистості, які створюють відповідні стани психіки i спонукають діяльність військових фахівців. Мотиваційна готовність курсантів до професійної діяльності визначається відповідною спрямованістю та наявністю змісту цієї діяльності, професійними установками особистості.

Формування мотиваційної готовності майбутніх офіцерів ракетно-артилерійського озброєння до професійної діяльності $\epsilon$ динамічним процесом, який залежить від зовнішніх умов. У період професійної підготовки змінюються вимоги до професії, структура основних мотивів іiі набуття, професійний менталітет, духовні цінності, операційно-технічна сфера у зв'язку з появою інноваційних технологій та ін. Становлення військового фахівця залежить і від внутрішніх умов: змінюються уявлення людини 
про професію, критерії іï оцінки та способи самореалізації в ній (Гребенюк, 1997).

В процесі освоєння професії відбувається розвиток i трансформація мотиваційної структури суб'єкта діяльності. Такий розвиток відбувається у двох напрямах: у першому випадку, загальні мотиви особистості трансформуються в трудові; в другому - зі зміною рівня професіоналізації змінюється і система професійних мотивів.

Кожен вид людської діяльності характеризується своїми специфічними спонукальними мотивами. Мотивація військової служби та професійної діяльності $є$ процесом суб'єктивного перетворення особистістю умов i чинників соціального i професійного середовища в результаті усвідомлення і прийняття ïx змісту та значущості в активні спонукальні сили, що лежать в основі мислення, поведінки та вчинків військово-професійної діяльності. 3 огляду на це, сенс мотивації полягає в тому, щоб знайти саме такі дії, які відповідають основній, закріпленій у житті установці особистості майбутнього офіцера ракетноартилерійського озброєння.

Результатом професійного становлення майбутнього офіцера ракетно-артилерійського озброєння має бути: якісне виконання функціональних обов'язків за посадовим призначенням; вміння вибудовувати міжособистісні відносини 3 особовим складом; здатність бачити головне в службовій діяльності, чітко визначати цілі і проявляти наполегливість в їх досягненні, раціонально розподіляти обов'язки між військовослужбовцями, доводити почату справу до кінця; вміння адаптуватися до змін соціального середовища за рахунок загальноосвітньої і військово-професійної підготовки; прагнення до постійного самовдосконалення; впевненість у своїх здібностях і правильності вибору життєвого шляху тощо (Дмитерко-Карабин, 2004; Максименко, Мельник, \& Олексієнко, 2002).

Зважаючи на зазначене вище, закцентуємо увагу на мотиваційну готовність майбутніх офіцерів ракетноартилерійського озброєння до здійснення службової діяльності. Мотивація військових фахівців різноманітна. Під впливом об’єктивних умов і суб'єктивних чинників у курсантів формується 
мотиваційна готовність до військово-професійної діяльності. Залежно від прояву мотиваційної готовності виділимо три рівні:

1. Високий рівень мотивації - характеризується вираженою потребою у військово-професійному самовдосконаленні, переважанням соціальної ініціативи i творчої діяльності, що сприяють ефективному вирішенню навчально-бойових завдань, а також чіткою установкою на військову службу в Збройних Силах України.

2. Середній рівень мотивації - вирізняється мотиваційноціннісною структурою, в якій військово-корпоративні цінності не є визначальними в діяльності військовослужбовців.

3. Низький рівень мотивації - характеризується слабким проявом (або відсутністю) ціннісних орієнтацій і установок на військову службу.

Рівні мотиваційної готовності майбутніх офіцерів ракетноартилерійського озброєння мають певні критерії (індикатори), що характеризують різну ступінь їх включеності в систему ціннісних установок та орієнтацій.

Соціальну включеність курсантів, як прояв рівня їх мотиваційної готовності, визначає мотиваційна фіксованість соціальних норм i рольових вимог. Мотиваційна фіксованість соціальних норм демонструє, яка частина 3 усієї їх сукупності відповідає інтересам майбутніх офіцерів ракетно-артилерійського озброєння, в той час як мотиваційна фіксованість рольових вимог визначає службові обов'язки які військовий фахівець виконує 3 професійним інтересом.

Майбутні офіцери ракетно-артилерійського озброєння, в яких соціальна включеність у професійну діяльність реалізована повністю, мають високий рівень мотиваційної готовності. Курсанти, в яких соціальна включеність реалізована частково (наполовину), мають середній рівень мотиваційної готовності, а у кого соціальна включеність не реалізована, мають низький рівень мотиваційної готовності до професійної діяльності.

Мотиваційно-ціннісні відносини військових фахівців обумовлюються системою мотивів. Ми виділили декілька груп мотивів, що обумовлюють професійну діяльність офіцера ракетноартилерійського озброєння: призначення професії, професійна 
діяльність, професійне спілкування, прояви особистості в професії. Обгрунтуємо їх більш детальніше.

Мотиви, які впливають на розуміння сутності професії офіцера виникають і розвиваються як форма i міра професійної спрямованості, прийняття кінцевих цілей діяльності. Мотиви професійної діяльності відображають сформовані раніше потреби курсантів, актуалізовані в процесі взаємодії з професією (мотиви саморозкриття і самоствердження, матеріальні потреби, особливості характеру тощо). Цей вид мотивів пов'язуємо 3 особистісними якостями: наполегливістю, завзятістю, вимогливістю в досягненні кінцевого результату, сумлінністю, ретельністю виконання професійної діяльності.

Прагнення військовослужбовців утвердитися в професійній групі, гордість за колектив, солідарність в діяльності, прагнення до подолання труднощів, відображають мотиви професійного спілкування. Мотиви, спрямовані на прояв особистості в професії, виражають особливості самосвідомості особистості в умовах взаємодії з професією (переконаність у власній придатності, у володінні творчим потенціалом, в тому, що визначений шлях це і $\epsilon$ «моє покликання» тощо) (Потапчук, 2001; Ягупов, 2004).

Для більш точного виявлення рівнів мотиваційної готовності майбутніх офіцерів ракетно-артилерійського озброєння до професійної діяльності необхідна система критеріїв.

Перша група критеріїв - зовнішні, до яких відносяться: особливості професійної діяльності офіцера; результати психолого-педагогічної діяльності; дисциплінованість; прагнення до професійного самовдосконалення та самоствердження, до виконання обов'язків; володіння професійними знаннями, вміннями, навичками; працездатність на службі, адекватність дій в ситуації вирішення завдань військово-службового спрямування тощо. Результатом дії даних критеріїв $є$ досягнуті результати службової діяльності.

Друга група критеріїв - внутрішні (особистісні): переважання в структурі мотиваційної готовності майбутніх офіцерів утворень соціального спрямування; ступінь адекватності самооцінки керівного складу; позитивна самооцінка результатів діяльності; самооцінка ставленню до колег по службі, iii 
адекватність колективній оцінці особистості офіцера ракетноартилерійського озброєння. Результатом дії внутрішніх критеріїв мотиваційної готовності майбутніх офіцерів ракетноартилерійського озброєння виступають переважання в ієрархії пї структурних елементів мотиваційно-смислових утворень, а також задоволеність військових фахівців результатами своєї діяльності і соціальним становищем в офіцерському колективі.

Армія, як один 3 інститутів виховання молоді, покликана формувати не тільки особистісні та громадянські якості, необхідні всім громадянам (патріотизм, громадянську мужність, соціальна активність, вміння діяти в нестандартній обстановці), але і професійно важливі (вміння і мотиваційна готовність до виконання завдань за призначенням як у мирний час, так i в особливий період) якості. У військових закладах вищої освіти особлива увага приділяється створенню умов для формування в курсантів умінь і навичок для високої бойової виучки, фізичного загартування, уміння використовувати бойові можливості озброєння та техніки.

Для майбутніх офіцерів ракетно-артилерійського озброєння особливе значення має мотиваційний компонент, який визначає важливість обраної мотивації курсантів. Серед курсантів-випускників Одеської військової академії (всього 282чоловіки) було проведено опитування (2017-2018рр.), аналіз результатів якого дозволив виявити основні мотиви майбутніх військовослужбовців, визначити їх зміст, а також обгрунтувати ступінь мотиваційної готовності до виконання функціональних обов'язків.

Аналіз мотиваційної сфери, перспектив військової служби, намірів i прагнень майбутніх офіцерів ракетно-артилерійського озброєння дав підстави стверджувати, що домінуючими потребами курсантів є привабливість спеціальності - 42,1\% і фізична підготовка - 37,2 \%. Крім цього, до ціннісних пріоритетів курсантів відносимо: військову честь і гідність - 31,9\%; відносини 3 колегами по службі - 30,8 \%; отримання цивільної спеціальності за бюджетні кошти - 33,1 \%; соціальне становище $26,4 \%$; продовження сімейних традицій військової служби $26,3 \%$ та ін. 
Різноплановість ціннісних орієнтирів майбутніх офіцерів ракетно-артилерійського озброєння, подальше вироблення у них високоморальних якостей (захист Вітчизни, військова честь, гідність), сприяє підвищенню організаційного $\mathrm{i}$ виховного потенціалу науково-педагогічних працівників ВЗВО.

Вагомий вплив на підготовку курсантів має формування їх психологічної готовності, до якої відносимо розвиток пізнавальних психічних процесів (пам'ять, оперативність мислення, багатосторонне сприйняття), вольових (цілеспрямованість, стійкість, наполегливість, дисциплінованість та ін.) і соціальнопсихологічних (взаємодопомога, товариства) якостей; вміння адаптуватися до умов військової діяльності, контролювати свою поведінку. Основним чинником формування психологічної готовності майбутніх офіцерів ракетно-артилерійського озброєння до службової діяльності $€$ зміцнення професійних мотивів поведінки, вольових і розумових рис характеру, вдосконалення знань, умінь і навичок, психічних процесів.

Одним із показників ефективності освітнього процесу ВЗВО є психологічна готовність курсантів до майбутньої професійної діяльності, зокрема, оцінка здатності майбутніх військовослужбовців виконувати бойові завдання. Понад 59,3\% курсантів готові виконати свій конституційний i військовий обов'язок, а $31,2 \%$ - частково готові до цього. Результати опитування свідчать про домінування економічних інтересів у курсантів, і в той же час усвідомленість свого обов'язку, моральної готовності до відбиття зовнішньої агресії з боку інших держав, пов'язують з безпосереднім призначенням Сухопутних військ Збройних Сил України.

Ефективність підготовки майбутніх офіцерів ракетноартилерійського озброєння до професійної діяльності залежить від психологічного мікроклімату колективу. Під час обгрунтування позиції курсантів за ступенем впевненості у колегах по службі за умови виконання бойових завдань 15,8 \% відповіли, що впевнені повністю; 24,2 \% - впевнені в більшій мірі; 52,8 \% - менше впевнені. Отримані результати свідчать про доцільність управління психологічним кліматом усередині військових колективів. 
Організація освітнього процесу сприяє підготовці майбутніх офіцерів ракетно-артилерійського озброєння, проте вони повинні бути більше цілеспрямованими. Більшість курсантів оцінюють рівень своєї військово-професійної підготовки, як достатній. Знання та навички, отримані під час навчання, на думку курсантіввипускників, дозволяють повністю (38,5 \%) або частково (44,3\%) виконувати службові обов'язки, пов'язані із застосуванням озброєння і військової техніки на полі бою, тактичним вишколом, високою психологічною стійкістю.

За час навчання у військовому закладі вищої освіти істотно змінюється морально-психологічний клімат в колективі, відбувається позитивна динаміка психологічного стану курсантів, що сприяє спрямованості мотиваційного компонента, його націленості на необхідність набуття знань, умінь i навичок військово-професійної діяльності, а також становлення їх, як майбутніх офіцерів ракетно-артилерійського озброєння.

\section{Висновки}

Проведене дослідження дозволило зробити такі висновки:

- формуванню мотиваційної сфери курсантів необхідно приділяти увагу на державному рівні, створюючи передумови для позитивного ставлення майбутніх офіцерів ракетноартилерійського озброєння до виконання службових обов'язків;

- важливим напрямом підвищення мотиваційної готовності курсантів до службової діяльності $\epsilon$ реалізація можливостей освітнього процесу ВЗВО;

- 3 метою формування мотиваційної готовності майбутніх військовослужбовців до професійної діяльності важливо: оцінювати абітурієнтів не тільки за загальноосвітнім і фізичним критеріями, а також враховувати значення мотиваційного критерію, що дозволить виявляти військово-професійну спрямованість курсантів на початковому етапі їх підготовки; скоригувати освітні програми в контексті збільшення обсягів навчального часу на спеціальну, технічну і тактичну підготовку; поступово збільшувати ступінь самостійності курсантів, зокрема старших курсів 3 метою усвідомленого закріплення знань i практичних навичок. 
Перспективами подальших розвідок у даному напрямку вбачаємо розробку перспективних методик навчання, спрямованих на ефективне формування мотиваційної готовності майбутніх офіцерів ракетно-артилерійського озброєння до професійної діяльності.

\section{Література}

1. Бойко О. В. Технологія формування психологічної готовності майбутніх магістрів військово-соціального управління до виконання функцій керівників-лідерів. Військова освіта : зб. наук. пр. Київ : Наук.-метод. центр військової освіти $\mathrm{MOH}$ України. 2004. № 14. С. 126-135.

2. Гребенюк Г. С. Мотиваційна готовність курсантів і слухачів вищого військового учбового закладу до професійної діяльності (на прикладі спеціалістів пожежної безпеки МВС України) : автореф. дис. на здобуття наук. ступеня канд. психол. наук : 20.02.02 / Київ : Київський гум. ін-т. 1997. 17 с.

3. Дмитерко-Карабин Х. М. Мотиваційна готовність до професійної діяльності як психологічна проблема. Збірник наукових пращь: філософія, соціологія, психологія. ІваноФранківськ : Вид-во «Плай» Прикарпатського університету. 2004. Вип. 9. Ч. 2. С. 23-32.

4. Максименко С. Д., Мельник П. В., Олексієнко Б. М. Основи військової психології : навчальний посібник. Хмельницький : Видавництво Національної академії ПВУ. 2002. 532 c.

5. Потапчук С. М. Психологічна робота у Прикордонних військах України. Морально-психологічне забезпечення службової діяльності Прикордонних військ України : підручник. Хмельницький : НАПВУ. 2001. 150 с.

6. Ягупов В. В. Військова психологія: підручник. Київ : Тандем. 2004. 656 с. 
Маслий О. М.

Мотивационная готовность будущих офицеров ракетноартиллерийского вооружения как фактор их профессионального становления

\section{Аннотация}

В структуре профессиональной готовности будущих офицеров ракетно-артиллерийского вооружения к служебной деятельности важное место занимают мотивы как внутреннее побуждение личности к активности, связанное с удовлетворением определенных потребностей. Мотивационная готовность курсантов определяется соответствующей направленностью и наличием содержания деятельности, профессиональными установками личности. Выделена группа мотивов, обусловливающих профессиональную деятельность военных специалистов. Анализ мотивационной сферы дал основания выявить потребности курсантов: привлекательность специальности, физическая подготовка, воинская честь и достоинство, отношения с коллегами по службе, получение гражданской специальности за бюджетные средства, социальное положение, продолжение семейных традиций военной службы.

Ключевые слова: мотивационная готовность, потребности, мотивы, профессиональные установки, курсанты, военная служба.

Маслій О. М.

Мотиваційна готовність майбутніх офіцерів ракетноартилерійського озбросння як чинник їх професійного становлення

\section{Анотація}

У структурі професійної готовності майбутніх офіцерів ракетно-артилерійського озброєння до службової діяльності важливе місце займають мотиви як внутрішне спонукання особистості до активності, пов'язане із задоволенням певних 
потреб. Мотиваційна готовність курсантів визначається відповідною спрямованістю та наявністю змісту діяльності, професійними установками особистості. Виділено групу мотивів, що обумовлюють професійну діяльність військових фахівців. Аналіз мотиваційної сфери дав підстави виявити потреби курсантів: привабливість спеціальності, фізична підготовка, військова честь і гідність, відносини 3 колегами по службі, отримання цивільної спеціальності за бюджетні кошти, соціальне становище, продовження сімейних традицій військової служби.

Ключові слова: мотиваційна готовність, потреби, мотиви, професійні установки, курсанти, військова служба. 